GRASAS Y ACEITES 66 (1)

January-March 2015, e067

ISSN-L: 0017-3495

doi: http://dx.doi.org/10.3989/gya.0711142

\title{
Quality parameters of olive oil from stoned and nonstoned Koroneiki and Megaritiki Greek olive varieties at different maturity levels
}

\author{
E. Katsoyannos, A. Batrinou, A. Chatzilazarou, S.M. Bratakos, K. Stamatopoulos and V.J. Sinanoglou ${ }^{\bowtie}$ \\ Instrumental Food Analysis Laboratory, Department of Food Technology, Faculty of Food Technology and Nutrition, \\ Technological Educational Institution (TEI) of Athens, Ag. Spyridonos 12210, Egaleo, Greece \\ ${ }^{\square}$ Corresponding author: v_sinanoglou@yahoo.gr, vsina@teiath.gr
}

Submitted: 03 July 2014; Accepted: 27 October 2014

SUMMARY: Virgin olive oil is a natural functional food and its beneficial role in health as an integral ingredient of the Mediterranean diet is universally recognized. The effects of olive pitting, degree of ripeness and variety (Greek varieties Koroneiki and Megaritiki) were investigated on the physicochemical characteristics, antioxidant constituent contents and capacity and on the fatty acid profile of olive oil. Ripeness resulted in a decrease $(P<0.05)$ in phenolic and tocopherol contents and the unsaturated/saturated and C18:1 $\omega-9 / \mathrm{C} 18: 2 \omega-6$ fatty acid ratios. The pitting technique resulted in a significant increase in phenolic and tocopherol contents, in most cases, without significantly affecting the fatty acid profile and sums. Olive oils from the Koroneiki variety showed significantly higher $(P<0.05)$ monounsaturated/polyunsaturated fatty acid ratios, which are particularly important for the stability of the oil against oxidation. It was concluded that olive oil from pitted olives maintains a high content in bioactive compounds and a high level of antioxidant activity.

KEYWORDS: Fatty acids; Koroneiki and Megaritiki varieties; Olive oil; Pitting; Ripening process

RESUMEN: Parámetros de calidad de aceites de oliva de las variedades de aceitunas griegas Koroneiki y Megaritiki con hueso y deshuesadas con diferente grado de maduración. El aceite de oliva virgen es un alimento funcional natural cuyo papel como ingrediente esencial de la dieta mediterránea, con propiedades beneficiosas para la salud, ha sido reconocido universalmente. Se ha estudiado el efecto del deshuesado de las aceitunas, grado de maduración y variedad (variedades griegas Koroneiki y Megaritiki) sobre las características físico-químicas, perfil de ácidos grasos y capacidad de los componentes antioxidantes de los aceites de oliva. La maduración ocasionó una disminución $(\mathrm{P}<0,05)$ del contenido de fenoles y tocoferoles y de la relación de ácidos insaturados/

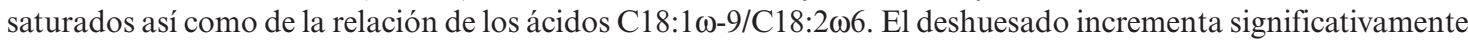
el contenido fenólico y de tocoferoles, sin afectar significativamente, en la mayoría de los casos, al perfil y cantidad de ácidos grasos. Los aceites de oliva de la variedad Koroneiki mostraron relaciones de ácidos grasos monoinsaturados/poliinsaturados significativamente mayores $(\mathrm{p}<0,05)$ que son particularmente importantes para la estabilidad del aceite frente a la oxidación. En conclusión, el aceite de oliva deshuesado mantiene un alto contenido de compuestos bioactivos y un alto nivel de actividad antioxidante.

PALABRAS CLAVE: Aceite de oliva; Ácidos grasos; Deshuesado; Proceso de maduración; Variedades Koroneiki y Megaritiki

Citation/Cómo citar este artículo: Katsoyannos E, Batrinou A, Chatzilazarou A, Bratakos SM, Stamatopoulos K, Sinanoglou VJ. 2015. Quality parameters of olive oil from stoned and nonstoned Koroneiki and Megaritiki Greek olive varieties at different maturity levels. Grasas Aceites 66 (1): e067. doi: http://dx.doi.org/10.3989/gya.0711142.

Copyright: (C) 2015 CSIC. This is an open-access article distributed under the terms of the Creative Commons Attribution-Non Commercial (by-nc) Spain 3.0 Licence. 


\section{INTRODUCTION}

The consumption of extra virgin olive oil is steadily increasing due to its unique sensory, nutritive qualities, biological properties and health promoting effects (Kalogeropoulos and Tsimidou, 2014, Jiménez et al., 2013). High contents of monounsaturated fatty acids (MUFAs) mainly oleic and poly-unsaturated fatty acids (PUFAs) (linoleic and linolenic acids) with beneficial effects on serum cholesterol, biological properties related to minor components, such as squalene (a chemo-preventive compound) chlorophylls and phytosterols, antioxidant compounds, (tocopherols, phenols, lignans, xylans) $\beta$-carotene and oleocanthal are considered rensponsible for its high dietary and biological value (Cárdeno et al., 2013). The recognized health benefits of olive oil have led to an increase in global demand and to the development of diversified olive oil products of advanced dietary quality, oxidative stability and health promoting biological properties. Many different products have been developed such as olive oil extracted from organic olives, un-ripe (green) olives, wild grown olives and pitted olives as well as products coming from specific regions labelled as protected designation of origin or geographical indication according to EU regulations (Ranalli et al., 2012, Del Caro et al., 2006).

The quality of virgin olive oil is influenced by a variety of factors such as geographical production area (altitude, edaphological characteristics, latitude), climatic conditions, cultivar and extraction process (Dag et al., 2011, Baccouri et al., 2008). Local oil varieties of the Mediterranean area are appreciated for their high quality and have indicative physicochemical characteristics, stability parameters and fatty acid profile (Ranalli et al., 2012). Consequently, it is important to analyze and fully characterize each local variety individually. Furthermore, the European Union evaluates the quality of Virgin Olive Oil according to sensory and physicochemical parameters (EEC, 1991, 2003). Koroneiki and Megaritiki are both oil cultivars of Oleaeuropaea L. originating from Greece, which produce olive oil of exceptional quality and are among the 20 cultivars which cover over $90 \%$ of the olive growing land in Greece (Kalogeropoulos and Tsimidou, 2014). The olive fruits of the Megaritiki variety are intended for olive oil and table olives production, while those of the Koroneiki variety are only for olive oil production. Koroneiki, the principal Greek oil-producing variety, is characterized by very high oil productivity and excellent quality of oil. This variety is resistant to adverse weather conditions, to insects and droughts and adapts to dry and moist regions. The Koroneiki variety olive oil is characterized by a special taste, aroma and rich composition in oleic acid and polyphenols making the oil very stable with superb health benefits.
The shelf-life for Koroneiki olive oil is exceptionally long compared to other varieties. The Megaritiki is a hardy, dual-purpose olive variety, widely used in Greece and has fruits that give a high oil yield of good quality (Kalogeropoulos and Tsimidou, 2014).

Another factor that greatly affects the quality of oil in terms of these features is the maturity grade of the olive (Jiménez et al., 2013). It is vital to determine the best harvesting time in order to optimize the sensory characteristics, which are improved as ripening progresses and the oxidative stability, which is reduced during ripening due to a decrease in total polyphenol content in ripe fruits (Cecchi et al., 2013, Caponio et al., 2001). Among the processing technologies, an innovative technique is the pitting $(\mathrm{P})$ of the olives before oil extraction, which leads to higher phenol and tocopherol values as well as better aroma characteristics, higher antioxidant activity and consequently greater stability and longer shelf-life than oils from whole olives (WO) (Ranalli et al., 2012, Ranalli et al., 2007, Amirante et al., 2006, Del Caro et al., 2006, Saitta et al., 2003).

The aim of the study was to evaluate basic quality parameters, minor components and antioxidant activity of extra virgin olive oils of cultivated olives of two common Greek varieties, Koroneiki and Megaritiki. The olive oil was also assessed according to the maturity level (green and ripe olives) and the processing technology by obtaining olive oil from whole and pitted fruits processed in a twophase decanter. Overall, this study has attempted to contribute in providing information regarding olive oil from pitted olives from the trees of Olea europea of Greek varieties.

\section{MATERIALS AND METHODS}

\subsection{Reagents and standards}

Analytical and HPLCgrade solvents were obtained from Merck (Darmstadt. Germany). All reagents used were of analytical grade and they were purchased from Mallinckrodt Chemical Works (St. Louis. MO) and from Sigma Chemical Co (Sigma-Aldrich Company, UK). Folin-Ciocalteau phenol reagent and free radical 2,2-diphenyl-1-picryl-hydrazyl (DPPH) were purchased from Sigma Chemical Co. (Sigma-Aldrich Company Ltd., Great Britain). The caffeic acid standard was of $98-99 \%$ purity and purchased from Sigma Chemical Co (SigmaAldrich Company Ltd., Great Britain). The fatty acid methyl esters used as GC standards were: lauric acid M-E, cis-5,8,11,14,17-eicosapentaenoic acid M-E and cis-4,7,10,13,16,19-docosahexaenoic acid M-E (purity $\geq 98 \%$ ) purchased from Sigma Chemical Co (Sigma-Aldrich Company. UK); Matreya Bacterial Acid Methyl Esters $\mathrm{CP}^{\mathrm{TM}}$ Mix; Supelco ${ }^{\mathrm{TM}} 37$ Component FAME Mix C4-C24; Supelco PUFA No.1.Marine Source. 


\subsection{Sampling}

Olive fruits (Olea europaea L.) were harvested in olive groves of the same area (Argolida-Greece) during two harvesting seasons from 2010/2011 to 2011/2012. Olive samples were categorized based on: a) variety (Megaritiki and Koroneiki) b) maturation stage (green and ripe) and c) paste preparation technique [whole (WO) and pitted fruit $(\mathrm{P})]$. Koroneiki olive fruits were typically small-sized, spherical in shape with one curved side, 12 to $15 \mathrm{~mm}$ in length and they weighed 1.5-2.5 g. The pit had the same shape as the fruit and the flesh/stone ratio was about 5.0-5.5/1 (w/w). Megaritiki olive fruits were small to mediumsized, with an average weight of $3.8-4.3 \mathrm{~g}$, and the $\mathrm{flesh} / \mathrm{pit}$ ratio was about 6.8-7.2/1 (w/w). The earliest maturation stage (green olives) was set for the middle of September and the latest (ripe olives) was set according to their skin color specified by the industrial optimum ripening stage (middle of December). For the two studied olive crops, the monthly average temperatures of these harvest periods were 27 and $12^{\circ} \mathrm{C}$, respectively. The average rainfall was 40 and $130 \mathrm{~mm}$, respectively. Samples for each maturation stage and variety were randomly picked from ten olive trees and put separately into 20 boxes (two samples per tree, one destined to be pitted and the other one to remain whole). Then the samples were processed in an olive oil plant (two phase decanter system), located in Argos (Peloponnese). Pitting was performed using a custommade tool. The oil samples obtained $(\mathrm{N}=20$ samples per variety, paste preparation technique and maturation stage, for the two harvesting seasons) were stored in hermetically sealed glass bottles for further analysis.

\subsection{Olive oil yield}

For oil content determination, $30 \mathrm{~g}$ of fruit samples (3 separate samples per variety, paste preparation technique, maturation stage and harvesting seasons) were dried in an oven at $80{ }^{\circ} \mathrm{C}$ to constant weight. The dry olives were extracted with hexane using a Soxhlet apparatus. The results were expressed as percentage of dry matter $(\% \mathrm{DM})$.

\subsection{Main quality parameters analysis}

The main quality parameters such as acidity value, ultra-violet light absorption K232 and K270 and peroxide value (PV) were determined by the methods reported in Regulation EEC/2568/91 of the European Union Commission.

For free acidity determination, $5 \mathrm{~g}$ of oil were added to $60 \mathrm{~mL}$ of an ethanol-diethyl ether $(1: 1 \mathrm{v} / \mathrm{v})$ mixture and neutralized with $0.1 \mathrm{~N} \mathrm{NaOH}$. The data obtained were expressed as $\mathrm{g}$ of oleic acid per $100 \mathrm{~g}$ of oil.

For the peroxide value determination, $1 \mathrm{~g}$ of oil was added to $25 \mathrm{~mL}$ of a mixture of acetic acid-chloroform $(3: 2 \mathrm{v} / \mathrm{v})$. Then, $0.5 \mathrm{~mL}$ of a saturated solution of KI was added to this mixture and the sample was kept in the dark for $5 \mathrm{~min}$. Afterwards, $75 \mathrm{~mL}$ of deionized water and $1 \mathrm{~mL}$ of starch paste, as indicator, were added to the above solution and the sample was titrated with $0.01 \mathrm{~N}$ sodium thiosulphate to complete bleaching. The data obtained were expressed as meq of $\mathrm{O}_{2} \cdot \mathrm{kg}^{-1}$ oil.

To determine the spectrophotometric indices K232 and K270, $0.5 \mathrm{~g}$ of olive oil were filtered through filter paper and weighed and then were put into a $50 \mathrm{~mL}$ volumetric flask. The flask was made up to volume with isooctane for spectrophotometry. The samples were analyzed in $1.000 \mathrm{~cm}$ cuvettes, using a double-beam ultraviolet-visible spectrophotometer Hitachi U-3210 (Hitachi, Ltd., Tokyo, Japan).

\subsection{Phenol content determination}

Phenolic compounds were isolated from a solution of oil in n-hexane by triple-extraction with methanol. Then the extracts of the three-step extraction were collected and passed through a $0.45-\mu \mathrm{m}$ pore-size membrane filter (Minisart, Sartorious, Goettingen, Germany) and they were analyzed colorimetrically for total phenol determination, using the Folin-Ciocalteau reagent according to the method described by Lafka et al. (2011). The absorbance of the samples was measured at $725 \mathrm{~nm}$ against a blank using a double-beam ultravioletvisible spectrophotometer Hitachi U-3210 (Hitachi, Ltd., Tokyo, Japan). Caffeic acid served as the standard for preparing the calibration curve and ranged from 60 to $140 \mu \mathrm{g} \cdot 25 \mathrm{~mL}^{-1}$ of assay solution. Results were expressed as $\mathrm{mg}$ of caffeic acid per $\mathrm{kg}$ of oil. In addition, the antioxidant activity of the phenolic extracts of the studied olive oils was measured as described in Section 2.6.

\subsection{Antioxidant activity- DPPH radical method}

The antiradical activity of the phenol extracts was determined using the 2,2,-diphenyl-2-picrylhydrazyl (DPPH) assay according to the method described by Lafka et al. (2011). Methanolic solutions of the extracts $(0.1 \mathrm{~mL})$ and $3.9 \mathrm{~mL}$ methanolic solution of DPPH $\left(0.0025 \mathrm{~g} \cdot 100 \mathrm{~mL}^{-1} \mathrm{CH}_{3} \mathrm{OH}\right)$ were added in a cuvette and the absorbance was measured at $515 \mathrm{~nm}$ using a double-beam ultraviolet-visible spectrophotometer Hitachi U-3210 (Hitachi, Ltd., Tokyo, Japan). As a control, $0.1 \mathrm{~mL}$ methanol was added instead of the extracts. The spectrophotometer was calibrated with pure methanol. Antioxidant activity was expressed as the percentage inhibition of the DPPH radical and was calculated according to the following equation:

$$
\mathrm{AA}(\%)=\left[\left(\mathrm{A}_{0}-\mathrm{A}_{\mathrm{i}}\right) / \mathrm{A}_{0}\right] \times 100
$$


Where $\mathrm{A}_{0}$ is the absorbance at $515 \mathrm{~nm}$ of the blank sample at time $\mathrm{t}=0 \mathrm{~min}$ and $\mathrm{A}_{\mathrm{i}}$ is the final absorbance of the sample at $515 \mathrm{~nm}$.

\subsection{HPLC analysis of tocopherols}

The oil sample $(1.5 \mathrm{~g})$ was dissolved in $10 \mathrm{~mL}$ of hexane, passed through a $0.45-\mu \mathrm{m}$ pore-size membrane filter (Minisart, Sartorious, Goettingen, Germany) and injected into the HPLC system. The equipment used was a HITACHI coupled to an autosampler L-2200, pump L-2130, column oven L-2300 and diode array detector L-2455 and controlled by Agilent EZChrom Elite software. The column was a Pinnacle II RP C18, $3 \mu \mathrm{m}, 150 \times 4.6 \mathrm{~mm}$ (Restek). The column oven was set at $30{ }^{\circ} \mathrm{C}$. The mobile phase was $5.0 \%$ water in methanol. The program run was isocratic, the run time was $20 \mathrm{~min}$ and the injection volume was $20 \mu \mathrm{L}$. The detector was operated at $295 \mathrm{~nm}$. Tocopherols were identified by comparing their retention times with $\alpha-, \beta-, \gamma-$ and $\delta$-tocopherol standards obtained from SigmaAldrich (St. Louis, MO). Tocopherol quantification was achieved using a calibration curve $\left(r^{2}=0.998\right)$ obtained for $\alpha$-tocopherol standard solutions (with different concentrations: $0.5,1.0,2.0,4.0,8.0$, $12.0,16.0$ and $20.0 \mu \mathrm{g} \mu \mathrm{L}^{-1}$ ) by plotting peak area against concentration, under the same chromatogram conditions. Results were expressed as $\mathrm{mg}$ of $\alpha$-tocopherol $\mathrm{kg}^{-1}$ oil. The detection limit (DL) was calculated based on signal-to-noise $(\mathrm{S} / \mathrm{N}) \leq 3$ and the quantification limit (QL) based on $\mathrm{S} / \mathrm{N} \leq 10$. DL and was found at $0.02 \mu \mathrm{g} \cdot \mu \mathrm{L}^{-1}$ and $0.04 \mu \mathrm{g} \cdot \mu \mathrm{L}^{-1}$, respectively.

\subsection{Gas chromatography analysis of fatty acid methyl esters}

The fatty acid methyl esters (FAME) of total lipids (TL) were prepared according to the procedure described by Sinanoglou and Miniadis-Meimaroglou (1998). Both quantitative and qualitative analyses were performed on an Agilent 6890 Series Gas Chromatograph(Agilent Technologies, Palo Alto, CA) equipped with a flame ionization detector, as described by Sinanoglou et al. (2013). A DB-23 capillary column $(60 \mathrm{~m} \times 0.25 \mathrm{~mm}$ i.d. $0.15 \mu \mathrm{m}$ film $)(50 \%$-cyanopropylmethylpolysiloxane) (Agilent Technologies) was used. The individual FAME were identified by comparing their retention times with those of the authentic standard mixtures. The relative content of fatty acids in the sample was determined according to Sinanoglou et al. (2013).

\subsection{Statistical analysis}

All determinations $(\mathrm{N}=20$ samples per variety, paste preparation technique and maturation stage) were carried out in triplicate. Values were averaged and reported along with the standard deviation (S.D.) or standard error (S.E.). All data were analyzed with One-Way ANOVA Post Hoc Tests and pairwise multiple comparisons were conducted with the Tukey's honestly significant difference test. Possibilities less than 0.05 were considered as statistically significant $(P<0.05)$. The pearson correlation was performed in order to test the relationships among the maturation stage (green and ripe) and the paste preparation technique [whole (WO) and the pitted fruit (P)]. All statistical calculations were performed with the SPSS package (IBM SPSS Statistics, version 19.0, Chicago, IL, USA) statistical software for Windows.

\section{RESULTS AND DISCUSSION}

\subsection{Main quality parameters}

Olives were assessed according to the olive maturity level (ripe or green), paste preparation technique (whole or pitted) or variety (Megaritiki and Koroneiki) and reported as mean values with standard deviation. All studied olive oils could be classified as extra virgin olive oil (EVOO) as experimentally obtained values (Table 1) were within the limits of The European Union (Commission Regulation (EC) No 1989/2003). The oils were produced from olive fruits which were harvested and processed within two days, so they were not exposed to hydrolytic or oxidative damage. All free acidity values remained below the limits reported by Regulation EEC/1989/2003 of the European Union Commission (EEC, 2003), which prescribes a value below $0.8 \mathrm{~g}$ of oleic acid per $100 \mathrm{~g}$ for a virgin olive oil. Moreover, the ultraviolet characteristics and peroxide value $(\mathrm{PV})$ of the olive oils studied fell within the ranges established by Regulation EC/1989/2003, for "extra virgin olive oil" category (K270 $\leq 0.22$, $\mathrm{K} 232 \leq 2.5$ and $\mathrm{PV} \leq 20 \mathrm{meq} \mathrm{O}_{2} \cdot \mathrm{kg}^{-1}$ ). The $\mathrm{K} 232$ value is an indication of conjugated polyunsaturated fatty acids in olive oil whereas $\mathrm{K} 270$ is an indication of carbonylic compounds (aldehydes and ketones).

Regarding the maturity level (ripe or green), a slight but not significant rise in free acidity was observed as ripening progressed (Table 1). It is already reported that the ripening process makes the fruit more sensitive to pathogenic and mechanical damage and increases enzymatic activity mainly of the lipolytic enzymes, which increase free acidity (Hamidoghli et al., 2008, Baccouri et al., 2008). The peroxide and K232 values presented a significant $(P<0.05)$ increase (Table 1$)$ during ripening progress, probably due to the greater amounts of conjugated acids (Caponio et al., 2001). Spectrophotometric absorption K270 also showed significantly $(P<0.05)$ higher values but only in whole fruit ripe samples as an effect of harvesting time, in accordance with Del Caro et al. (2006), but remained statistically 
TABLE 1. Influence of variety, technology and ripening process on the main quality parameters of whole and pitted green and ripe olive oils of the Megaritiki and Koroneiki varieties

\begin{tabular}{|c|c|c|c|c|c|c|c|c|}
\hline \multirow[b]{2}{*}{ Variety/maturity } & \multicolumn{2}{|c|}{ Megaritiki ripe } & \multicolumn{2}{|c|}{ Megaritiki green } & \multicolumn{2}{|c|}{ Koroneiki ripe } & \multicolumn{2}{|c|}{ Koroneiki green } \\
\hline & WO & $\mathbf{P}$ & WO & $\mathbf{P}$ & WO & $\mathbf{P}$ & WO & $\mathbf{P}$ \\
\hline $\begin{array}{l}\text { Olive oil yield } \\
\text { (\% DM) }\end{array}$ & $20.56 \pm 1.74 \mathrm{a}$ & $16.50 \pm 1.56 \mathrm{~b}$ & $11.32 \pm 1.73 \mathrm{c}$ & $11.46 \pm 1.06 \mathrm{c}$ & $21.94 \pm 1.43 \mathrm{a}$ & $16.77 \pm 2.10 \mathrm{~b}$ & $11.89 \pm 1.65 \mathrm{c}$ & $12.92 \pm 1.80 \mathrm{c}$ \\
\hline $\begin{array}{l}\text { Free Acidity } \\
(\% \mathrm{C} 18: 1)\end{array}$ & $0.29 \pm 0.03 \mathrm{a}$ & $0.24 \pm 0.01 b$ & $0.25 \pm 0.02 \mathrm{ba}$ & $0.24 \pm 0.01 \mathrm{~b}$ & $0.36 \pm 0.02 \mathrm{c}$ & $0.28 \pm 0.02 \mathrm{a}$ & $0.32 \pm 0.02 \mathrm{c}$ & $0.23 \pm 0.03 b$ \\
\hline K 232 & $2.28 \pm 0.02 \mathrm{a}$ & $2.34 \pm 0.02 b$ & $2.13 \pm 0.02 \mathrm{c}$ & $2.25 \pm 0.02 \mathrm{a}$ & $1.53 \pm 0.01 \mathrm{~d}$ & $1.71 \pm 0.02 \mathrm{e}$ & $1.40 \pm 0.01 \mathrm{f}$ & $1.48 \pm 0.02 \mathrm{~g}$ \\
\hline K 270 & $0.14 \pm 0.01 \mathrm{a}$ & $0.16 \pm 0.01 \mathrm{a}$ & $0.12 \pm 0.01 \mathrm{~b}$ & $0.15 \pm 0.01 \mathrm{a}$ & $0.14 \pm 0.01 \mathrm{a}$ & $0.15 \pm 0.01 \mathrm{a}$ & $0.11 \pm 0.01 b$ & $0.13 \pm 0.01 \mathrm{ab}$ \\
\hline $\begin{array}{l}\text { Peroxide Value } \\
\left(\text { meq } \mathrm{O}_{2} \cdot \mathrm{kg}^{-1}\right)\end{array}$ & $3.7 \pm 0.3 \mathrm{a}$ & $2.9 \pm 0.2 b$ & $3.1 \pm 0.2 b$ & $2.4 \pm 0.2 \mathrm{c}$ & $4.5 \pm 0.3 \mathrm{~d}$ & $3.1 \pm 0.2 b$ & $2.8 \pm 0.2 b$ & $2.4 \pm 0.1 \mathrm{c}$ \\
\hline
\end{tabular}

Results represent means \pm SD $(n=20$ separate samples). Means in the same row bearing different small letters (a, $b$, c, ect.) differ significantly $(P<0.05)$.

DM (dry matter), WO (whole fruit), P (pitted fruit)

unchanged in the case of pitted, ripe fruit samples. Gimeno et al. (2002) did not observe any difference in peroxide and $\mathrm{K} 270$ values during ripening while Salvador et al. (2001) and Baccouri et al. (2008) reported that PV and UV absorption at $270 \mathrm{~nm}$ diminished during ripening, a result which is contrary to our findings. Also, Hamidoghli et al. (2008), assessing the impact of harvesting time on olive oil quality and quantity from three olive varieties, Roghani, Zard and Lechino, found that UV absorption at $232 \mathrm{~nm}$ (K232) increased and peroxide value and UV absorption at $270 \mathrm{~nm}$ (K270) decreased during ripening.

Regarding the paste preparation technique, the oil of pitted fruits $(\mathrm{P})$ had significantly lower values of free acidity and peroxide value than the oil of the whole fruit (WO) samples. These results were comparable to those reported by Saitta et al. (2003). Del Caro et al. (2006) reported that the free acidity of the pitted sample was lower, but the peroxide value had no statistically significant fluctuation and Amirante et al. (2006) reported that no difference was noticed in relation to the olive paste preparation technique. K232 showed a significant increase due to the pitting process in accordance with Del Caro et al. (2006) findings. Spectrophotometric absorption K270 did not display a clear trend in the present study.

Overall, the two studied varieties, Megaritiki and Koroneiki, showed that there were statistically significant $(P<0.05)$ differences in free acidity and K232 values (Table 1), with higher K232 values found for Megaritiki. On the contrary, peroxide and K270 values were quite similar in the two studied varieties.

Extraction yield values show tendencies toward the technology effect (whole/pitted) and the impact of ripeness (Table 1). The degree of maturation and the paste preparation both affect the oil yield. The oil content (expressed as \% of fresh weight) increased $(P<0.05)$ with fruit ripening in both varieties, in accordance with other researchers' findings (Mahhou et al., 2012). Concerning the paste preparation technique, the oil yield was not significantly influenced in the case of green fruits, whereas a significant change was observed in ripe fruits as pitted ripe fruit oils have lower yields. This result confirmed that pitting has the disadvantage of lower yields as stated by other studies (Patumi et al., 2003). No differences were detected between varieties (Table 1).

Oil content varies by variety from less than $10 \%$ to about $30 \%$ on a dry weight basis. National statistical data show that the extractability of the oil from the fruit is influenced by fruit moisture content, maturity, paste preparation process and extraction machinery type. The yields vary significantly depending on the crop year, operating system, planting density, growing practices, climate conditions and the biological alternation of the olive tree (European Commission, 2012).

\subsection{Phenols, tocopherols and antioxidant activity}

Phenols, tocopherols and antioxidant activity were also evaluated according to the olive maturity stage (ripe or green), paste preparation technique (whole or pitted) and variety (Kalamata or Megaritiki) (Table 2). In Megaritiki variety oils, the phenol content varied between 222.99 and $306.71 \mathrm{mg} \cdot \mathrm{kg}^{-1}$, while in the Koroneiki variety between 226.49 and $352.19 \mathrm{mg} \cdot \mathrm{kg}^{-1}$. Stefanoudaki et al. (2011) reported that the two-phase decanter extraction, which can operate without the addition of water, produced oils with high phenolic concentrations and resistance to oxidation because the loss in hydrophilic phenolic compounds in the vegetation water is reduced.

Ripening affected the phenol and tocopherol contents of the olive oils, as the values of green olive oils were significantly higher $(P<0.05)$ than ripe olive oils in both varieties. This result is in agreement with previous studies that have indicated that 
TABLE 2. Values of phenols, tocopherols, sensory score and antioxidant activity of whole and pitted green and ripe olives of the Megaritiki and Koroneiki varieties

\begin{tabular}{|c|c|c|c|c|c|c|c|c|}
\hline \multirow[b]{2}{*}{ Variety/maturity } & \multicolumn{2}{|c|}{ Megaritiki ripe } & \multicolumn{2}{|c|}{ Megaritiki green } & \multicolumn{2}{|c|}{ Koroneiki ripe } & \multicolumn{2}{|c|}{ Koroneiki green } \\
\hline & WO & $\mathbf{P}$ & WO & $\mathbf{P}$ & WO & $\mathbf{P}$ & WO & $\mathbf{P}$ \\
\hline $\begin{array}{l}\text { Phenols mg } \\
\text { caffeic acid· } \\
\mathrm{kg}^{-1} \text { oil }\end{array}$ & $222.99 \pm 11.06 a$ & $258.05 \pm 11.53 b$ & $283.88 \pm 13.03 \mathrm{c}$ & $306.71 \pm 18.25 \mathrm{c}$ & $226.49 \pm 13.01 \mathrm{a}$ & $303.45 \pm 19.82 \mathrm{c}$ & $285.10 \pm 12.33 \mathrm{c}$ & $352.19 \pm 17.96 \mathrm{~d}$ \\
\hline $\begin{array}{l}\text { Tocopherols mg } \\
\alpha \text {-tocopherol- } \\
\mathrm{kg}^{-1} \text { oil }\end{array}$ & $340.09 \pm 26.91 \mathrm{a}$ & $382.82 \pm 29.40 \mathrm{a}$ & $452.91 \pm 30.01 \mathrm{bd}$ & $562.11 \pm 38.32 \mathrm{~cd}$ & $393.64 \pm 22.52 \mathrm{a}$ & $485.50 \pm 38.93 \mathrm{bd}$ & $437.22 \pm 24.11 \mathrm{~b}$ & $506.30 \pm 36.42 \mathrm{~d}$ \\
\hline $\begin{array}{l}\text { Antioxidant } \\
\text { Activity }\end{array}$ & $22.45 \pm 1.61 \mathrm{a}$ & $23.25 \pm 1.25 \mathrm{ab}$ & $25.35 \pm 2.07 \mathrm{ab}$ & $26.88 \pm 2.60 b$ & $22.60 \pm 1.64 \mathrm{a}$ & $26.23 \pm 2.07 b$ & $25.40 \pm 2.03 \mathrm{ab}$ & $27.28 \pm 2.32 b$ \\
\hline
\end{tabular}

Results represent means $\pm \mathrm{SD}(\mathrm{n}=20$ separate samples). Means in the same row bearing different small letters $(\mathrm{a}, \mathrm{b}, \mathrm{c}$, ect. $)$ differ significantly $(P<0.05)$. WO (whole fruit), P (pitted fruit).

the tocopherol content is greater in green olive oils and decreases as ripening occurs (Salvador et al., 2001, Beltrán et al., 2005, Hamidoghli et al., 2008). Also, Caponio et al. (2001) found a decrease in many EVOO compounds (phenols, tocopherols, pigments) in the case of Coratina and Ogliarola salentina cultivars and also in oxidation stability as ripening proceeded. These authors also noted that phenolic compounds and degree of olive ripeness influenced the organoleptic characteristics and shelf-life of EVOO. Antioxidant activity, although higher in green olive oils, did not show any statistically significant differences. Correlation between phenol or tocopherol content and antioxidant activity was calculated with respect to the maturation stage. Results showed that phenol and tocopherol contents had a higher correlation with the antioxidant activity in ripe olive oils $(r=0.908$ and $0.919, p \leq 0.01)$ than in green olive oils $(r=0.726$ and $0.725, p \leq 0.01)$.

The paste preparation technique also contributed to the differences in the contents of phenols and tocopherols. The phenols of pitted olive oils were higher than whole olive oils in both varieties. Tocopherols were also higher in pitted olive oils with significant differences in the Koroneiki variety. In agreement with the above results Ranalli et al. (2012) reported that removal of the pit from fruit before processing is an innovative technique that strongly enhanced the already high quality level of this oil variety. Antioxidant activity was also increased in pitted olive oils but was not significantly higher. Luaces et al. (2007) reported a $25 \%$ increase in total phenolic compounds in oil obtained from pitted olive fruits of three main Spanish cultivars. Furthermore, the correlations of phenol and tocopherol content vs antioxidant activity did not seem to be affected by the pitting process (for whole fruit oil $r=0.885$ and 0.867 , respectively and for pitted fruit oil $r=0.849$ and 0.864 , respectively, $p \leq 0.01$ ). According to Del Caro et al. (2006) the major advantage to using pitted paste is that it improves the sensory qualities and shelf-life of extra virgin olive oil. In the pitting process, the stones are removed at the beginning of processing and therefore, the enzymes (lipoxygenases, peroxidases) contained in the seeds do not influence the pulp composition and phenols are not enzymatically degraded thus improving their concentration and oil oxidative stability. Moreover, solid particles, responsible for a rough taste in the olive oil are no longer a problem, and thermal and mechanical activities that cause the degradation of minor and major components of olive oil are reduced (Saitta et al., 2003). Amirante et al. (2006) also evaluated the quality of VOOs obtained when a pitting mechanism was used for the olive paste preparation in comparison to the use of a traditional stone mill and showed that resistance to oxidation, total phenols and pleasant volatile compounds were higher in the pitted olive oils than in the oils obtained from the whole olive paste, results that were also confirmed by other authors (Ranalli et al., 2007).

According to the literature data, several factors can affect the quantitative phenolic profiles of olive fruits and include the ripening process, the geographical origin, the olive tree variety and the rainfall frequency as having major impact (Beltrán et al., 2005). The tocopherol and total phenol composition of the Koroneiki variety virgin olive oils studied showed significant variations compared to those reported by Allalout et al. (2009) and Dabbou et al. (2009) for virgin olive oil of the Koroneiki variety grown in Northern Tunisia and in North-East Tunisia, respectively. These results indicate that the environmental factor affects the concentration of bioactive compounds. No substantial $(P>0.05)$ differences between the Megaritiki and Koroneiki varieties were observed regarding the whole olive oils' total phenol and tocopherol contents. In contrast, the Koroneiki pitted olive oils' total phenol content was found significantly higher than its content in the Megaritiki pitted olive oils. Concerning the total tocopherol content, Koroneiki pitted, ripe olive oils had a significantly higher value than the Megaritiki one. 


\subsection{Fatty acid profile}

The GC-FID analysis from Megaritiki and Koroneiki olive varieties' lipids revealed the presence of 25 fatty acids (FA) (Table 3). Palmitic acid (C16:0) was the main saturated fatty acid (SFA) in all the examined samples. Oleic acid $(\mathrm{C} 18: 1 \omega-9)$ contributed the most to the total concentration of monounsaturated fatty acid (MUFA) and linoleic acid

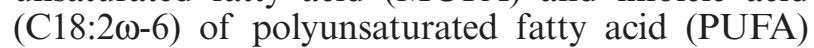
across all types of samples. Palmitoleic, stearic, $\gamma$-linolenic and arachidic acids were also determined in lower proportions in all the studied samples.

The fatty acid proportions showed slight or significant $(P<0.05)$ variances during the ripening process and in relation to the paste preparation technique and the olive variety. Several authors (Dag et al., 2011, Allalout et al., 2009) reported that agronomic parameters including olive variety, fruit ripening and climatic conditions (autumn temperatures, relative humidity and rain fall frequency) could affect the olive oil fatty acid composition.

As ripening progresses for both varieties of olive oils, palmitic, palmitoleic and linoleic acid proportions increased $(P<0.05)$, oleic acid proportion decreased and cis-vaccenic acid proportion did not show any significant $(P>0.05)$ variation. In accordance to the above results, several researchers (Salvador et al., 2001, Hamidoghli et al., 2008, Oueslati et al., 2009, Dag et al., 2011) reported that ripening caused an increase in linoleic acid content and a decrease in oleic acid content because of oleate desaturase enzyme activity, which converts oleic acid to linoleic acid. It has already been mentioned that the temperature drop from the earliest maturation stage (September) to the latest (DecemberJanuary) enhances the desaturation of oleate to linoleate in oil seeds (Dag et al., 2011). Rondanini et al. (2014) reported that the palmitic acid proportion during ripening was altered in an opposite trend, depending on the olive variety. Stearic and a-linolenic acid proportions in the Megaritiki variety olive oils did not show any significant $(P>0.05)$ variation during ripening, whereas in the Koroneiki variety oils, stearic and a-linolenic acid proportions showed a significant decrease and increase, respectively. It is reported that stearic acid does not accumulate during the ripening process (Dag et al., 2011). In the course of fruit ripening, $C 22: 1 \omega-9$ in the Megaritiki variety olive oils decreased below the detection limits of the method. Moreover, in both varieties, the sum of saturated fatty acids (SFA) and the $\mathrm{C} 16: 0 / \mathrm{C} 18: 0$ ratio increased $(P<0.05)$ during ripening, whereas the sum of monounsaturated fatty acids (MUFA) as well as MUFA/SFA, MUFA/ PUFA and C18:1 $\omega-9 / \mathrm{C} 18: 2 \omega-6$ ratios significantly $(P>0.05)$ decreased. In addition, as maturation proceeded, the PUFA/SFA ratio remained statistically immutable. In the case of the sum of polyunsaturated fatty acids (PUFA), the two varieties exhibited differences. In fact, the PUFA proportion in the Megaritiki oil samples showed no substantial differentiation, whereas in in Koroneiki oils it increased significantly during maturation. Finally, ripening caused a significant decrease in the UFA/ SFA ratio in both varieties, which indicates that the selected PUFA increase was compensated by an SFA increase. The decreasing trend of the MUFA/ PUFA and C18:1 $\omega-9 / C 18: 2 \omega-6$ ratios found during the maturity process is in accordance with the results obtained by other authors (Bengana et al., 2013, Dag et al., 2011).

The paste preparation technique did not affect the main fatty acid proportions of the Megaritiki and Koroneiki variety olive oils. Moreover, no significant changes were observed in the sums of saturated (SFA), monounsaturated (MUFA) and polyunsaturated (PUFA) fatty acids or in their ratios. However, as shown in Table 3, the proportions of several minor fatty acids exhibited significant variations. Therefore, regarding the Megaritiki variety olive oils, iso-C16:0 and iso-C17:0 were found significantly higher in WO oils, whereas $\mathrm{C} 17: 0$ and $\mathrm{C} 20: 1 \omega-9$ were lower than in the $\mathrm{P}$ oils.

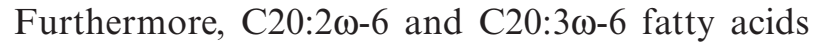
were not detected in the Megaritiki variety $\mathrm{P}$ oils. No significant $(P>0.05)$ differences were observed in the Koroneiki variety WO or P oil samples with respect to their minor fatty acid composition, except for iso-C17:0 of the $\mathrm{P}$ oils, and the proportion decreased below the detection limits of the method.

The most significant differences in the fatty acid profile results were found mainly among varieties and secondary in relation to maturation stage and paste preparation technique. In accordance with that finding, it has been suggested that the genotype effect is a major contributor to oil quality parameters (de la Rosa et al., 2013). Nevertheless, all the values of fatty acids found were in conformity to those of the International Olive Oil Council's regulation (IOOC, 2013). The Koroneiki variety olive oils were higher in oleic, stearic and arachidic acids and significantly lower in palmitic, palmitoleic, linoleic and cis-vaccenic acids, compared to the Megaritiki olive oils. These variations reflect differences in the sums of fatty acids and their ratios. Consequently, the C16:0/C18:0 ratio was found significantly lower in the Koroneiki variety olive oils than in the Megaritiki variety. Furthermore, in the Koroneiki variety oils the MUFA/PUFA and the C18:1/C18:2 ratios were found at more than 50\% compared to the Megaritiki olive oils. As these ratios represent the most marked relationship with oil stability (Oueslati et al., 2009), the Koroneiki variety oils could be characterized as having limited oxidation risk. 
TABLE 3. Fatty acid composition $[\%(w / w)]$ in total lipids of olive oil varieties

\begin{tabular}{|c|c|c|c|c|c|c|c|c|}
\hline \multirow{2}{*}{$\begin{array}{l}\text { Variety/maturity } \\
\text { Fatty acids }\end{array}$} & \multicolumn{2}{|c|}{ Megaritiki ripe } & \multicolumn{2}{|c|}{ Megaritiki green } & \multicolumn{2}{|c|}{ Koroneiki ripe } & \multicolumn{2}{|c|}{ Koroneiki green } \\
\hline & WO & $\mathbf{P}$ & WO & $\mathbf{P}$ & WO & $\mathbf{P}$ & WO & $\mathbf{P}$ \\
\hline $\mathrm{C} 10: 0$ & $0.08 \pm 0.01 \mathrm{a}$ & $0.08 \pm 0.00 \mathrm{a}$ & $0.07 \pm 0.00 \mathrm{~b}$ & $0.07 \pm 0.00 \mathrm{~b}$ & $0.02 \pm 0.00 \mathrm{c}$ & $0.02 \pm 0.00 \mathrm{c}$ & - & - \\
\hline C14:0 & $0.11 \pm 0.00 \mathrm{a}$ & $0.11 \pm 0.00 \mathrm{a}$ & $0.04 \pm 0.00 \mathrm{~b}$ & $0.03 \pm 0.00 \mathrm{c}$ & $0.02 \pm 0.00 \mathrm{~d}$ & $0.02 \pm 0.00 \mathrm{~d}$ & $0.02 \pm 0.00 \mathrm{~d}$ & $.01 \pm 0.00 \mathrm{e}$ \\
\hline C15:0 & $0.06 \pm 0.00 \mathrm{a}$ & $0.06 \pm 0.00 \mathrm{a}$ & $0.04 \pm 0.00 \mathrm{~b}$ & $0.03 \pm 0.00 \mathrm{c}$ & $0.02 \pm 0.00 \mathrm{~d}$ & $0.02 \pm 0.00 \mathrm{~d}$ & $0.02 \pm 0.00 \mathrm{~d}$ & $0.01 \pm 0.00 \mathrm{e}$ \\
\hline C16:0 & $14.29 \pm 0.42 \mathrm{a}$ & $14.26 \pm 0.38 \mathrm{a}$ & $13.44 \pm 0.29 b$ & $13.26 \pm 0.33 b$ & $12.21 \pm 0.25 \mathrm{c}$ & $12.24 \pm 0.26 \mathrm{c}$ & $10.77 \pm 0.22 \mathrm{~d}$ & $10.61 \pm 0.24 \mathrm{~d}$ \\
\hline iso- $\mathrm{C}$ & $20 \pm 0.01 \mathrm{a}$ & $0.17 \pm 0.01 b$ & $0.16 \pm 0.01 b$ & $0.12 \pm 0.01 \mathrm{c}$ & $0.13 \pm 0.01 \mathrm{c}$ & $0.13 \pm 0.01 \mathrm{c}$ & $0.10 \pm 0.00 \mathrm{~d}$ & \\
\hline C16:1 & $2.76 \pm 0.09 \mathrm{a}$ & $2.68 \pm 0.08 \mathrm{a}$ & $2.22 \pm 0.07 b$ & $2.27 \pm 0.08 \mathrm{~b}$ & $1.32 \pm 0.05 \mathrm{c}$ & $1.28 \pm 0.06 \mathrm{c}$ & $1.05 \pm 0.05 \mathrm{~d}$ & $1.04 \pm 0.04 \mathrm{~d}$ \\
\hline iso- $\mathrm{C}$ & $.10 \pm 0.01 \mathrm{a}$ & $0.04 \pm 0.00 \mathrm{~b}$ & $0.09 \pm 0.00 \mathrm{a}$ & $0.04 \pm 0.00 \mathrm{~b}$ & $0.02 \pm 0.00 \mathrm{c}$ & - & $0.02 \pm 0.00 \mathrm{c}$ & - \\
\hline $\mathrm{C} 17: 0$ & $0.03 \pm 0.00 \mathrm{a}$ & $0.09 \pm 0.01 b$ & $0.02 \pm 0.00 \mathrm{c}$ & $0.08 \pm 0.00 \mathrm{~b}$ & $0.02 \pm 0.00 \mathrm{c}$ & $0.02 \pm 0.00 \mathrm{c}$ & $0.02 \pm 0.00 \mathrm{c}$ & $0.01 \pm 0.00 \mathrm{~d}$ \\
\hline $\mathrm{C} 17: 1$ & $0.07 \pm 0.00 \mathrm{a}$ & $0.07 \pm 0.00 \mathrm{a}$ & $0.06 \pm 0.00 \mathrm{~b}$ & $0.06 \pm 0.00 \mathrm{~b}$ & $0.06 \pm 0.00 \mathrm{~b}$ & $0.05 \pm 0.00 \mathrm{c}$ & $0.04 \pm 0.00 \mathrm{~d}$ & $0.04 \pm 0.00 \mathrm{~d}$ \\
\hline C18:0 & $.55 \pm 0.09 \mathrm{a}$ & $2.54 \pm 0.11 \mathrm{a}$ & $2.45 \pm 0.10 \mathrm{a}$ & $2.41 \pm 0.08 \mathrm{a}$ & $3.55 \pm 0.12 b$ & $3.54 \pm 0.13 b$ & $4.58 \pm 0.14 \mathrm{c}$ & $4.53 \pm 0.11 \mathrm{c}$ \\
\hline $\mathrm{C} 18: 1 \omega-9$ & $62.29 \pm 0.69 a$ & $62.34 \pm 0.61 \mathrm{a}$ & $63.88 \pm 0.58 b$ & $63.94 \pm 0.57 b$ & $70.56 \pm 0.61 \mathrm{c}$ & $70.61 \pm 0.62 \mathrm{c}$ & $72.41 \pm 0.64 d$ & $72.91 \pm 0.68 \mathrm{~d}$ \\
\hline $\mathrm{C} 18: 1 \omega-7$ & $3.93 \pm 0.11 \mathrm{a}$ & $3.92 \pm 0.10 \mathrm{a}$ & $3.98 \pm 0.09 \mathrm{a}$ & $3.97 \pm 0.11 \mathrm{a}$ & $1.99 \pm 0.07 \mathrm{~b}$ & $2.01 \pm 0.06 \mathrm{~b}$ & $2.09 \pm 0.08 \mathrm{~b}$ & $.01 \pm 0.07 \mathrm{~b}$ \\
\hline $\mathrm{C} 18: 2 \omega-6$ & $11.64 \pm 0.14 \mathrm{a}$ & $11.87 \pm 0.16 \mathrm{a}$ & $11.22 \pm 0.13 b$ & $11.34 \pm 0.18 b$ & $8.07 \pm 0.16 \mathrm{c}$ & & & \\
\hline $\mathrm{C} 18: 3$ & $0.03 \pm 0.00 \mathrm{a}$ & & $0.04 \pm 0.00 \mathrm{c}$ & & & & & \\
\hline C18: & $.84 \pm 0.05 a$ & & $0.82 \pm 0.04 \mathrm{a}$ & $0.85 \pm 0.05 \mathrm{a}$ & & & & $0.67 \pm 0.03 b$ \\
\hline C20:0 & $.36 \pm 0.01 \mathrm{a}$ & $0.38 \pm 0.01 \mathrm{ab}$ & $0.40 \pm 0.01 b$ & $0.40 \pm 0.01 \mathrm{~b}$ & $0.50 \pm 0.02 \mathrm{c}$ & $0.52 \pm 0.02 \mathrm{c}$ & & $0.37 \pm 0.01 \mathrm{a}$ \\
\hline$C 20: 1 \omega-9$ & $.14 \pm 0.01 \mathrm{a}$ & $0.17 \pm 0.01 b$ & $0.18 \pm 0.01 b$ & $0.22 \pm 0.01 \mathrm{c}$ & $0.02 \pm 0.00 \mathrm{~d}$ & $0.02 \pm 0.00 \mathrm{~d}$ & $0.01 \pm 0.00 \mathrm{e}$ & - \\
\hline$C 20: 2 \omega-6$ & $0.09 \pm 0.00 \mathrm{a}$ & - & $0.12 \pm 0.01 \mathrm{~b}$ & - & $0.34 \pm 0.01 \mathrm{c}$ & & $0.28 \pm 0.01 \mathrm{~d}$ & $0.26=$ \\
\hline$C 20: 3 \omega-6$ & $0.09 \pm 0.01 \mathrm{a}$ & - & & - & $0.01 \pm 0.00 \mathrm{~b}$ & & $0.01 \pm 0.00 \mathrm{~b}$ & $0.02 \pm 0.00 \mathrm{c}$ \\
\hline $\mathrm{C} 20: 4 \omega-6$ & $0.09 \pm 0.01 \mathrm{a}$ & $0.07 \pm 0.00 \mathrm{~b}$ & $0.10 \pm 0.01 \mathrm{a}$ & $0.25 \pm 0.01 \mathrm{c}$ & $0.02 \pm 0.00 \mathrm{~d}$ & $0.02 \pm 0.00 \mathrm{~d}$ & $0.02 \pm 0.00 \mathrm{~d}$ & $0.02 \pm 0.00 \mathrm{~d}$ \\
\hline$C 20: 3 \omega-3$ & - & - & - & - & $0.16 \pm 0.01 \mathrm{a}$ & $0.18 \pm 0.01 \mathrm{c}$ & $0.14 \pm 0.01 \mathrm{c}$ & $0.12 \pm 0.01 \mathrm{~b}$ \\
\hline$C 20: 5 \omega-3$ & $10 \pm 0.01 \mathrm{a}$ & $0.10 \pm 0.01 \mathrm{a}$ & $0.11 \pm 0.01 \mathrm{a}$ & $0.11 \pm 0.01 \mathrm{a}$ & - & - & - & - \\
\hline C22:0 & $0.11 \pm 0.00 \mathrm{a}$ & $0.10 \pm 0.00 \mathrm{~b}$ & $0.15 \pm 0.01 \mathrm{c}$ & $0.15 \pm 0.01 \mathrm{c}$ & - & - & - & - \\
\hline $\mathrm{C} 22: 1 \mathrm{a}$ & - & - & & & $0.03 \pm 0.00 \mathrm{c}$ & & & \\
\hline $\mathrm{C} 24: 0$ & $4 \pm 0.00 \mathrm{a}$ & $0.05 \pm 0.00 \mathrm{~b}$ & $0.19 \pm 0.01 \mathrm{c}$ & $0.17 \pm 0.01 \mathrm{c}$ & $0.10 \pm 0.00 \mathrm{~d}$ & & & \\
\hline SFA & $17.93 \pm 0.38 \mathrm{a}$ & $17.88 \pm 0.30 \mathrm{a}$ & $17.05 \pm 0.31 b$ & $16.76 \pm 0.27 b$ & $16.59 \pm 0.22 \mathrm{c}$ & $16.63 \pm 0.23 \mathrm{c}$ & $16.02 \pm 0.21 \mathrm{~d}$ & $15.74 \pm 0.20 \mathrm{~d}$ \\
\hline MUFA & $69.19 \pm 0.45 \mathrm{a}$ & $69.18 \pm 0.47 \mathrm{a}$ & $70.41 \pm 0.50 \mathrm{~b}$ & $70.65 \pm 0.52 b$ & $73.98 \pm 0.63 \mathrm{c}$ & $74.00 \pm 0.54 \mathrm{c}$ & $75.63 \pm 0.61 d$ & $76.03 \pm 0.58 \mathrm{~d}$ \\
\hline PUFA & $12.88 \pm 0.32 \mathrm{a}$ & $12.94 \pm 0.33 \mathrm{a}$ & $12.51 \pm 0.36 \mathrm{a}$ & $12.59 \pm 0.31 \mathrm{a}$ & $9.43 \pm 0.23 b$ & $9.37 \pm 0.27 b$ & $8.35 \pm 0.21 \mathrm{c}$ & $8.23 \pm 0.26 c$ \\
\hline MUFA/SFA & $3.86 \pm 0.03 \mathrm{a}$ & $3.87 \pm 0.05 \mathrm{a}$ & $4.13 \pm 0.05 b$ & $4.22 \pm 0.07 \mathrm{~b}$ & $4.46 \pm 0.05 \mathrm{c}$ & $4.45 \pm 0.04 c$ & $4.72 \pm 0.05 \mathrm{~d}$ & $4.83 \pm 0.06 \mathrm{~d}$ \\
\hline MUFA/ PUFA & $5.37 \pm 0.05 \mathrm{a}$ & $5.35 \pm 0.06 \mathrm{a}$ & $5.63 \pm 0.08 \mathrm{~b}$ & $5.61 \pm 0.07 \mathrm{~b}$ & $7.84 \pm 0.09 \mathrm{c}$ & $7.90 \pm 0.08 \mathrm{c}$ & $9.06 \pm 0.11 \mathrm{~d}$ & $9.24 \pm 0.13 \mathrm{~d}$ \\
\hline PUFA/SFA & $0.72 \pm 0.03 \mathrm{a}$ & $0.72 \pm 0.04 \mathrm{a}$ & $0.73 \pm 0.03 \mathrm{a}$ & $0.75 \pm 0.04 \mathrm{a}$ & $0.57 \pm 0.04 \mathrm{~b}$ & $0.56 \pm 0.03 \mathrm{~b}$ & $0.52 \pm 0.03 b$ & $0.52 \pm 0.02 b$ \\
\hline UFA/ SFA & $4,58 \pm 0.05 \mathrm{a}$ & $4.59 \pm 0.06 \mathrm{a}$ & $4.86 \pm 0.08 \mathrm{~b}$ & $4.97 \pm 0.07 \mathrm{~b}$ & $5.03 \pm 0.09 b$ & $5.01 \pm 0.08 b$ & $5.24 \pm 0.10 \mathrm{c}$ & $5.35 \pm 0.12 \mathrm{c}$ \\
\hline $\mathrm{C} 16: 0 / \mathrm{C} 18: 0$ & $5.60 \pm 0.03 \mathrm{a}$ & $5.61 \pm 0.05 \mathrm{a}$ & $5.48 \pm 0.04 \mathrm{~b}$ & $5.50 \pm 0.04 \mathrm{~b}$ & $3.44 \pm 0.04 \mathrm{c}$ & $3.46 \pm 0.04 \mathrm{c}$ & $2.35 \pm 0.03 \mathrm{~d}$ & $2.34 \pm 0.03 d$ \\
\hline $\mathrm{C} 18: 1 \omega-9 / \mathrm{C} 18: 2 \omega-6$ & $5.35 \pm 0.08 \mathrm{a}$ & $5.25 \pm 0.07 \mathrm{a}$ & $5.69 \pm 0.08 \mathrm{~b}$ & $5.64 \pm 0.07 \mathrm{~b}$ & $8.74 \pm 0.11 \mathrm{c}$ & $8.82 \pm 0.12 \mathrm{c}$ & $10.06 \pm 0.13 \mathrm{~d}$ & $10.22 \pm 0.16 \mathrm{~d}$ \\
\hline
\end{tabular}

Results represent means $\pm \mathrm{SD}(\mathrm{n}=20$ separate samples). Means in the same row bearing different small letters (a, b, c, ect.) differ significantly $(\mathrm{P}<0.05)$.

WO (whole fruit), P (pitted fruit).

\section{CONCLUSIONS}

All the studied olive oils could be classified as extra virgin olive oil (EVOO). Regarding the basic quality parameters of olive oil, the ripeness of olives resulted in a slight but not significant rise in free acidity of the oil, and the oil from the pitted fruits $(\mathrm{P})$ had significantly lower values of free acidity and peroxide value than the oil of whole fruit
(WO) samples. Ripening affected the phenol and tocopherol contents of the olive oils, as the values of green olive oils were significantly higher than ripe olive oils in both varieties. The phenols of the pitted olive oils were higher than the whole olive oils in both varieties. Tocopherols were also higher in the pitted olive oils with significant differences in the Koroneiki variety. The paste preparation technique did not affect the main fatty acid proportions of 
the Megaritiki and Koroneiki variety olive oil. The most significant differences in the fatty acid profile results were found mainly between varieties with the Koroneiki variety exhibiting a fatty acid profile less prone to oxidation. In conclusion, this study confirms the fact that Koroneiki and Megaritiki, which are local oil varieties of the Mediterranean area, are characterized by excellent quality oil parameters and that the pitting technique results in olive oil that maintains a high content of bioactive compounds.

\section{REFERENCES}

Allalout A, Krichène $\mathrm{D}$, Methenni $\mathrm{K}$, Taamalli $\mathrm{A}$, Oueslati I, Daoud D, Zarrouk M. 2009. Characterization of virgin olive oil from Super Intensive Spanish and Greek varieties grown in northern Tunisia. Sci. Hortic. 120, 77-83. http:// dx.doi.org/10.1016/j.scienta.2008.10.006.

Amirante P, Clodoveo ML, Dugo G, Leone A, Tamborrino A. 2006. Advance technology in virgin olive oil production from traditional and de-stoned pastes: Influence of the introduction of a heat exchanger on oil quality. Food Chem. 98, 797-805. http://dx.doi.org/10.1016/ j.foodchem.2005.07.040.

Baccouri O, Guerfel M, Baccouri B, Cerretani L, Bendini A, Lercker G, Zarrouk M, Ben Miled DD. 2008. Chemical composition and oxidative stability of Tunisian monovarietal virgin olive oils with regard to fruit ripening. Food Chem. 109, 743-754. http://dx.doi.org/10.1016/ j.foodchem.2008.01.034

Beltrán G, Paz Aguilera M, Del Rio C, Sanchez S, Martinez L. 2005. Influence of fruit ripening process on the natural antioxidant content of Hojiblanca virgin olive oils. Food Chem. 89, 207-215. http://dx.doi.org/10.1016/ j.foodchem.2004.02.027.

Bengana M, Bakhouche A, Lozano-Sánchez J, Amir Y, Youyou A, Segura-Carretero A, Fernández-Gutiérrez A. 2013. Influence of olive ripeness on chemical properties and phenolic composition of Chemlal extra-virgin olive oil. Food Res. Int. 54, 1868-1875. http://dx.doi.org/10.1016/ j.foodres.2013.08.037.

Caponio F, Gomes T, Pasqualone A. 2001. Phenolic compounds in virgin olive oils: influence of the degree of olive ripeness on organoleptic characteristics and shelf-life. European Food Res. Technol. 212, 329-333. http://dx.doi.org/10.1007/ s002170000268.

Cárdeno A, Sánchez-Hidalgo M, Alarcón-De-La-Lastra C. 2013. An up-date of olive oil phenols in inflammation and cancer: Molecular mechanisms and clinical implications. Curr. Med. Chem. 20, 4758-4776. http://dx.doi.org/10.2174 109298673113209990159 .

Cecchi L, Migliorini M. Cherubini C, Giusti M, Zanoni B, Innocenti M, Mulinacci N. 2013. Phenolic profiles, oil amount and sugar content during olive ripening of three typical Tuscan cultivars to detect the best harvesting time for oil production. Food Res. Int. 54, 1876-1884. http:// dx.doi.org/10.1016/j.foodres.2013.04.033.

Commission Regulation (EEC) No $2568 / 91$ of July 1991. On the characteristics of olive and olive pomace oils and on their analytical methods. Off. J. Eur. Comm. L 248, 5 September 1991, pp. 1-83.

Commission Regulation (EC) No 1989/2003 of 6 November 2003 amending Regulation (EEC) No 2568/91 on the characteristics of olive oil and olive-pomace oil and on the relevant methods of analysis. Official Journal of the European Communities L 295, 6 November 2003, pp. 57-77.

Dabbou S, Issaoui M, Servili M, Taticchi A, Sifi S, Montedoro GF, and Hammami M. 2009. Characterisation of virgin olive oils from European olive cultivars introduced in Tunisia. Eur. J. Lipid Sci.Technol. 111, 392-401. http:// dx.doi.org/10.1002/ejlt.200800032.
Dag A, Kerem Z, Yogev N, Zipori I, Lavee S, Ben-David E. 2011. Influence of time of harvest and maturity index on olive oil yield and quality. Sci. Hort. 127, 358-366. http:// dx.doi.org/10.1016/j.scienta.2010.11.008.

de la Rosa R, Talhaoui N, Rouis H, Velasco L, León L. 2013. Fruit characteristics and fatty acid composition in advanced olive breeding selections along the ripening period. Food Res. Int. 54, 1890-1896. http://dx.doi. org/10.1016/j.foodres.2013.08.039.

Del Caro A, Vacca V, Poiana M, Fenu P, Piga A. 2006. Influence of technology, storage and exposure on components of extra virgin olive oil (Bosana $\mathrm{cv}$ ) from whole and de-stoned fruits. Food Chem. 98, 311-316. http://dx.doi.org/10.1016/j. foodchem.2005.05.075.

European Commission, Directorate-General for Agriculture and Rural Development Economic analysis of the olive sector Latest update: July 2012.

Gimeno E, Castellote AL, Lamuela-Raventoa RM, DelaTorre MC, Lopez-Sabater MC. 2002. The effect of harvest and extraction methods on the antioxidation content (phenolics, $\alpha$ - tocopherol, and $\beta$ - carotene) in virgin olive oil. Food Chem. 78, 207-211. http://dx.doi.org/10.1016/ S0308-8146(01)00399-5.

Hamidoghli Y, Jamalizadeh S, Malakroudi MR. 2008. Determination of harvesting time effect on quality and quantity of olive (Olea europea L.) oil in Roudbar regions. Journal of Food Agric. Envi. 6, 238-241.

International Olive Oil Council (IOOC). 2013. Trade standard applying to olive oil and olive-pomace oil. COI/T.15/NC No 3/Rev. 7, May 2013. Available from www.internationaloliveoil.org.

Jiménez B, Sánchez-Ortiz A, Lorenzo ML, Rivas A. 2013. Influence of fruit ripening on agronomic parameters, quality indices, sensory attributes and phenolic compounds of Picudo olive oils. Food Res. Int. 54, 1860-1867. http:// dx.doi.org/10.1016/j.foodres.2013.08.016.

Kalogeropoulos N, Tsimidou MZ. 2014. Antioxidants in Greek Virgin Olive Oils. Antioxidants, 3, 387-413. http://dx.doi. org/10.3390/antiox3020387.

Lafka T-I, Lazou AE, Sinanoglou VJ, Lazos ES. 2011. Phenolic and antioxidant potential of olive oil mill wastes. Food Chem. 125, 92-98. http://dx.doi.org/10.1016/ j.foodchem.2010.08.041.

Luaces P, Romero C, Gutierrez F, Sanz C, Perez AG. 2007. Contribution of olive seed to the phenolic profile and related quality parameters of virgin olive oil. J. Sci. Food Agric. 87, 2721-2727. http://dx.doi.org/10.1002/ jsfa.3049.

Mahhou A, Nabil Y, Hadiddou A, Oukabli A, Mamouni A. 2012. Performance of the Arbequina, Haouzia and Menara olive varieties in rainfed conditions in the Meknès region of Morocco. OLIVAE, Official magazine of the International Olive Council 118, 3-21.

Oueslati I, Anniva C, Daoud D, Tsimidou MZ, Zarrouk M. 2009. Virgin olive oil (VOO) production in Tunisia: The commercial potential of the major olive varieties from the arid Tataouine zone. Food Chem. 112, 733-741. http:// dx.doi.org/10.1016/j.foodchem.2008.06.041.

Patumi M, Terenziani S, Ridolfi M, Fontanazza G. 2003. Effect of Fruit Stoning on Olive Oil Quality. J. Am. Oil Chem. Soc. 80, 249-255. http://dx.doi.org/10.1007/s11746-003-0685-1.

Ranalli A, Benzi M, Gomes T, Delcuratolo D, Marchegiani D, Lucera L. 2007. Concentration of natural pigments and other bioactive components in pulp oils from de-stoned olives. Innov. Food Sci. Emerg. Technol. 8, 437-442. http:// dx.doi.org/10.1016/j.ifset.2007.03.020.

Ranalli F, Ranalli A, Contento S, Casanovas M, Antonucci M, Di Simone G. 2012. Concentrations of Bioactives and Functional Factors in Destoned Virgin Olive Oil: The Case Study of the Oil from Olivastra di Seggiano Cultivar. J. Pharm. Nutrit. Sci. 2, 83-93.

Rondanini DP, Castro DN, Searles PS, Rousseaux MC. 2014. Contrasting patterns of fatty acid composition and oil accumulationduring fruit growth in several olive varieties and locations in a non-Mediterranean region. Eur. J. Agron. 52, 237-246. 
10 E. Katsoyannos, A. Batrinou, A. Chatzilazarou, S.M. Bratakos, K. Stamatopoulos and V.J. Sinanoglou

Saitta M, Lo Turco V, Pollicino D, Dugo G, Bonaccorsi L, Amirante P. 2003. Oli di oliva da pasta denocciolataottenuta da cv Coratina e Paranzana. Rivi. Ital. Sost. Grass. 80, 27-34.

Salvador MD, Arande F, Fregapane G. 2001. Influence of fruit ripening on Cornibara virgin olive oil quality. A study of four successive crops seasons. Food Chem. 73, 45-53. http:// dx.doi.org/10.1016/S0308-8146(00)00276-4.

Sinanoglou VJ, Strati IF, Bratakos SM, Proestos C, Zoumpoulakis P, Miniadis-Meimaroglou S. 2013. On the combined application of Iatroscan-TLC-FID and GC-FID to identify total, neutral and polar lipids and their fatty acids extracted from foods. ISRN Chromatog. ID 859024, http://dx.doi. org/10.1155/2013/859024.

Sinanoglou VJ, Miniadis-Meimaroglou S. 1998. Fatty acid of neutral and polar lipids of (edible) Mediterranean cephalopods. Food Res. Int. 31, 467-473. http://dx.doi.org/10.1016/ S0963-9969(99)00014-9.

Stefanoudaki E, Koutsaftakis A, Harwood JL. 2011. Influence of malaxation conditions on characteristic qualities of olive oil. Food Chem. 127, 1481-1486. http://dx.doi.org/ 10.1016/j.foodchem.2011.01.120. 